\title{
Surface decontamination - a prerequisite for safe production of muscle food: A review
}

\author{
M. Sinhamahapatra ${ }^{1 *}$ and S. Biswas ${ }^{2}$
}

${ }^{1}$ School of Agriculture, Indira Gandhi National Open University, Maidan Garhi, Delhi-110 068, India; ${ }^{2}$ Department of Livestock Product Technology, West Bengal University of Animal and Fishery Sciences, Kolkata-700 037, West Bengal, India

\begin{abstract}
There is paradigm shift in the acceptability of food in terms of food quality and safety in the recent past. Muscle food (meat/fish) can be source of various food-borne pathogens of significant public health concern. If sufficient control measures are not adopted for hygienic and wholesome production, the unsafe meat/fish can cause a number of food-borne illnesses. Therefore, various surface decontamination methods are used as important control measures in the meat/fish processing for ensuring the food safety by reducing the biological food hazards. Besides the conventional physical and chemical methods of decontamination, biological methods and some novel decontamination technologies like non-thermal physical methods are also being applied by the researchers/processors to ensure the muscle food safety and avoid the adverse effects of some of the conventional methods. This review is focussed on the compilation of up-to-date information related to the effectiveness of various surface decontamination methods, so that the researchers and other stakeholders can select the effective and suitable decontamination method for future research or industry application. The scope of this review is limited to the surface decontamination treatments studied for muscle food safety during the period from 2010 to 2021.
\end{abstract}

Key words: Biological, Chemical, Muscle foods, Novel decontamination, Physical

\section{Highlights:}

- Surface decontamination of muscle food as control measure improves food safety.

- Thermal physical treatments are safe, cheap, but may affect sensory quality at high temperature.

- Chemical treatments are cheap, but may have residue and affect sensory quality at high concentration.

- Novel technologies are eco-friendly, effective antimicrobial and don't affect sensory quality much.

- Hurdle technology for surface decontamination is better approach for meat/fish industry.

\section{Introduction}

Food safety is a public health priority because every year almost 1 in 10 people in the world suffers and more than 4 lakh people die every year from food borne illness after consuming the contaminated food (WHO, 2020). Some food borne illnesses are associated with food contamination with harmful chemicals, but majority of the food borne illnesses are because of the food borne pathogens like Salmonella, Campylobacter, Enterohaemorrhagic Escherichia coli and
Listeria. Muscle foods like meat (including poultry) and fish (fin fish and shell fish) products are great sources of these pathogens and there lies the importance of ensuring the safety of muscle foods.

Even after production of meat animals following all the good animal husbandry practices, contamination of meat carcasses during slaughter and processing is inevitable. The meat carcass surface gets microbial contamination from various sources like skin, feet, feather (in poultry), faecal contamination 
from gastro-intestinal tract during dressing of carcass etc (Das et al., 2019). Similarly, fish may get contaminated with microbes from scales, skin, shell, viscera, faceal content, water etc. Pre-slaughter/pre-harvest factors like livestock/fish production practices may inadvertently result in pathogenic contamination in meat and fish. Post-slaughter/post-harvest factors that may lead to microbial contamination of meat/fish include unhygienic handling, storage, transportation and distribution of meat/fish; complex processing techniques and equipment; and inappropriate handling of meat/fish by consumers etc. There is a great chance of surface contamination of meat/fish during processing because of cross contamination from food handlers, processing equipment, unhygienic work surface, contaminated water, air, dust etc. The emerging pathogens, especially the antibiotic-resistant pathogens are new challenges in the process of ensuring food safety. All these factors lead to unsafe muscle food and ultimately food borne illnesses in the consumers.

The muscle food safety can be ensured by adopting Good Animal Husbandry Practices (GAHP), Good Aquaculture Practices (GAqP), Good Manufacturing Practices (GMP), Good Hygienic Practices (GHP), Hazard Analysis and Critical Control Points (HACCP) system and other food safety and management systems. As effective control measures in HACCP system, various intervention strategies like physical, chemical, biological surface decontamination treatments can be applied alone or in combination to reduce foodborne pathogens in muscle food. As these treatments have their own advantages and disadvantages, the processing industry has to decide their application as per the suitability of the treatment, scale of the operation, the rules and regulations of the meat producing country and requirement of the importing countries.

\section{Pathogens of food safety concern in muscle food}

The most prevalent and emerging pathogens of meat and poultry products are Campylobacter jejuni, Salmonella typhimurium, E. coli $\mathrm{O} 157: \mathrm{H7}$, other Enterohemorrhagic E. coli (EHEC), Listeria monocytogenes, Bacillus cereus, Clostridium botulinum, Staphylococcus aureus, Yersinia enterocolitica, Mycobacterium paratuberculosis, Hepatitis E virus, Avian influenza virus, Toxoplasma gondi etc. Fish can also be source of pathogens like Listeria monocytogenes, multiple drug resistant Salmonella Newport, Vibrio spp., E. coli, Yersinia spp., Brucella spp., Shigella spp., Streptococcus iniae, Klebsiella spp., Clostridium botulinum, Piscirickettsia salmonis, Edwardsiella piscicida, Lactococcus garvieae, reovirus, norovirus, herpesvirus etc. (Novoslavskij et al., 2016).

In the USA during 2017, 360 food borne disease outbreaks were reported and most common food categories associated with these outbreaks were molluscs (19\% of outbreaks), fish (17\%), chicken (11\%), and beef (9\%). The most common pathogens associated with these outbreaks were norovirus, salmonella (Enteritidis, Typhimurium, Newport, Heidelberg, Braenderup serotypes), and Shiga toxin-producing E. coli (STEC) (CDC, 2017). During 2017-18, 1060 cases of listeriosis and 216 deaths were reported in South Africa due to contamination of ready-to-eat meat with L. monocytogenes (WHO, 2020).

\section{Regulatory requirements for microbiological safety of muscle foods}

To ensure the supply of safe food to the domestic consumers, all the meat and fish producers/processors/sellers in India have to follow the Food Safety and Standard Act and Regulations implemented by the Food Safety and Standards Authority of India (FSSAI). For hygienic production of meat/fish products, the producers have to comply with the microbiological standard requirements for these products. As per the Food Safety and Standard Regulations (FSSR), the fresh or chilled meat should not have more than $10^{6} \log \mathrm{CFU} / \mathrm{g}$ aerobic plate count (APC), $10^{4} \log \mathrm{CFU} / \mathrm{g}$ yeast 
and mould count, $10^{3} \log \mathrm{CFU} / \mathrm{g}$ E.coli and Staph. aureus; and the Salmonella should be absent in $25 \mathrm{~g}$ sample (FSSR, 2011). The chilled and frozen fin fish and crustacean should not contain more than $10^{7} \mathrm{CFU} / \mathrm{g}$ APC, 500/g E. coli; and their Salmonella and Vibrio cholerae count should be nil in $25 \mathrm{~g}$ sample 2011). Likewise, other countries also have their own food standards, hence exporting meat to other countries becomes challenging sometimes, especially when the importing countries have very stringent criteria of zero or near zero tolerance standard for some of the pathogens (example, Salmonella). Therefore, the control measures, like, surface decontamination of carcass may be adopted by the meat/fish industry to meet the national and international microbiological standards. In some countries where the consumers prefer consumption of raw fish (molluscs), surface decontamination is the prime step for ensuring the food safety.

The food safety authorities of various countries like United Sates Department of Agriculture-Food Safety and Inspection Services (USDA-FSIS), European Food Safety Authority (EFSA), Food Standards Australia New Zealand (FSANZ) etc. have guidelines for approving the surface decontamination treatments and set criteria like, these treatments should significantly reduce the target pathogens and should not pose any substantial public health risk. For example, USDA-FSIS has approved the application of hot water, steam, lactic acid, citric acid, acetic acid, ozone etc. and EFSA has approved lactic acid as carcass surface decontaminant.

\section{Thermal physical methods for surface decontamination of muscle foods}

The principle of all the following physical methods is the thermal destruction of microbes on the meat/fish surface:

Hot water washing / pasteurization: Hot water washing/pasteurization $\left(74-82{ }^{\circ} \mathrm{C}\right)$ results in reduction of E. coli and Enterobacteriaceae on lamb, beef and poultry carcass (Hauge et al.,
2011; Barco et al., 2015; Belluco et al., 2016). Hot water pasteurization $\left(82{ }^{\circ} \mathrm{C}\right.$ for $\left.8 \mathrm{sec}\right)$ significantly reduces the aerobic plate count, B. cereus, and reduces almost $99.5 \%$ of generic E. coli and thereby STEC on lamb carcass (Hauge et al., 2011). Though this treatment can cause discolouration of meat initially, but the colour is acceptable after $24 \mathrm{hrs}$ of storage (Hauge et al., 2011). The adverse effect on meat quality can be avoided by application of lower temperature for shorter time (few seconds).

Steam pasteurization and vacuuming: Steam pasteurization (above $82^{\circ} \mathrm{C}$ ) is commercially used for decontamination of whole carcass (Chen et al., 2012). It is more effective, but more expensive than hot water washing and can raise the surface temperature of carcass and affects meat colour and texture. Whereas, steam vacuuming is effective only for spot treatment (where steam is applied on the specific area, but not on entire carcass). In this process, first steam is applied and then vacuum is used to remove the condensed moisture and contamination from the carcass. It reduces total viable count (TVC) by 0.4- $0.9 \log$ $\mathrm{CFU} / \mathrm{cm}^{2}$ at different parts of beef carcass (Hochreutener et al., 2017). It also significantly reduces the Enterobacteriaceae and TVC on lamb carcass (Sandra Da Silva and Farag, 2020). It is costlier than hot water washing and can also have adverse effect on the meat appearance and tenderness, if the temperature is too high or applied for longer duration.

\section{Chemical methods for surface decontamination of muscle foods}

Various chemicals have been in use for surface decontamination of the meat carcass or fish for long. Though their uses started long back, but they are still useful because of various reasons like their antimicrobial effect, cost effectiveness, ease of application etc. Some of the studies conducted in the last decade are reviewed here (Table 1).

Organic acids: The researchers have evaluated 
Table 1. Overview of chemical surface decontamination treatments

\begin{tabular}{|c|c|c|c|}
\hline $\begin{array}{c}\text { Decontamination } \\
\text { treatment }\end{array}$ & Application & Microbial reduction & Reference \\
\hline \multirow{4}{*}{ Organic acids } & $\begin{array}{l}\text { Lactic acid }(2 \%) \text { and acetic } \\
\text { acid }(2 \%) \text { sprays for } 30 \\
\text { seconds on beef surface }\end{array}$ & $\begin{array}{l}0.9 \text { to } 2.2 \log \text { CFU in APC and } \\
\text { complete inhibition of enterococci }\end{array}$ & $\begin{array}{l}\text { Sallam et al., } \\
2020\end{array}$ \\
\hline & $\begin{array}{l}\text { Acetic acid spray ( } 2 \%, \text { for } \\
60 \text { seconds) on beef } \\
\text { carcass }\end{array}$ & $\begin{array}{l}0.8-\log \text { CFU, 1.54-log CFU and 1.4- } \\
\log \text { CFU in TPC, total coliform and } \\
\text { faecal coliform counts respectively }\end{array}$ & $\begin{array}{l}\text { Carranza } \\
\text { et al., } 2013\end{array}$ \\
\hline & $\begin{array}{l}\text { Peracetic acid }(50 \mathrm{ppm}) \text { on } \\
\text { Pangasius fish }\end{array}$ & $0.4-1.4 \log$ CFU/g, in E. coli & $\begin{array}{l}\text { Thi et al., } \\
2015\end{array}$ \\
\hline & $\begin{array}{l}\text { Lactic acid }(2.5 \%) \text { and } \\
\text { acetic acid }(2.5 \%) \text { on } \\
\text { rainbow trout fish }\end{array}$ & $\begin{array}{l}1 \text { and } 0.5 \log \text { CFU/g in APC, } 1.2 \\
\text { and } 1 \log \text { CFU/g in lactic acid } \\
\text { bacteria (LAB) respectively }\end{array}$ & $\begin{array}{l}\text { Dikici et al., } \\
2021\end{array}$ \\
\hline \multirow{6}{*}{$\begin{array}{l}\text { Chlorine based } \\
\text { productsCPC }\end{array}$} & $\begin{array}{l}\mathrm{ClO}_{2} \text { solution wash }(200 \\
\text { ppm for } 5 \text { minutes }) \text { on } \\
\text { chicken carcass }\end{array}$ & $\begin{array}{l}1.07 \log \mathrm{CFU} / \mathrm{cm}^{2} \text { in total viable } \\
\text { count and } 1.15 \log \mathrm{CFU} / \mathrm{cm}^{2} \text { in } \\
\text { coliform count }\end{array}$ & $\begin{array}{l}\text { Sefna et al. } \\
2019\end{array}$ \\
\hline & $\begin{array}{l}\text { Chlorinated water (50 } \\
\text { ppm) on Pangasius fish }\end{array}$ & $0-1.0 \log$ CFU/g in E. coli & $\begin{array}{l}\text { Thi et al., } \\
2015\end{array}$ \\
\hline & $\begin{array}{l}\text { ASC by DAR method } \\
(10 \mathrm{ppm} \text { for } 5 \mathrm{~min})\end{array}$ & $\begin{array}{l}\text { Completely inactivated E. coli } \\
\text { O157:H7, L. monocytogenes, S. } \\
\text { typhimurium and Staph. aureus }\end{array}$ & $\begin{array}{l}\text { Kim et al., } \\
2014\end{array}$ \\
\hline & $\begin{array}{l}\text { ASC (1200 ppm) on } \\
\text { chicken skin }\end{array}$ & $\begin{array}{l}1.2-1.8 \log _{10} \mathrm{CFU} / \mathrm{mL} \\
\text { in S. typhimurium }\end{array}$ & $\begin{array}{l}\text { Ilhak et al., } \\
2018\end{array}$ \\
\hline & $\begin{array}{l}\mathrm{ASC}(1200 \mathrm{ppm}) \text { on } \\
\text { rainbow trout }\end{array}$ & $\begin{array}{l}1.4 \log \mathrm{CFU} / \mathrm{g} \text { in } \mathrm{APC}, 1.2 \log \mathrm{CFU} / \\
\mathrm{g} \text { in LAB and } 1.56 \log \mathrm{CFU} / \mathrm{g} \text { in } \\
\text { Enterobacteriaceae }\end{array}$ & $\begin{array}{l}\text { Dikici et al., } \\
2021\end{array}$ \\
\hline & $\begin{array}{l}\text { CPC }(0.5 \%) \text { on chicken } \\
\text { skin }\end{array}$ & $\begin{array}{l}2.2-3.2 \log _{10} \mathrm{CFU} / \mathrm{mL} \text { in } L . \\
\text { monocytogenes }\end{array}$ & $\begin{array}{l}\text { Ilhak et al., } \\
2018\end{array}$ \\
\hline Ozone & $\begin{array}{l}\text { Ozone }(0.4 \mathrm{ppm}) \text { on chilled } \\
\text { poultry }\end{array}$ & $\begin{array}{l}\text { Significant reduction in Total } \\
\text { Aerobic Counts and } \\
\text { Enterobacteriaceae }\end{array}$ & $\begin{array}{l}\text { Cortesi et al., } \\
2011\end{array}$ \\
\hline \multirow[t]{2}{*}{ Tripolyphosphate } & $\begin{array}{l}\text { TSP ( } 12 \% \text { for } 30 \text { seconds) } \\
\text { on beef carcass }\end{array}$ & $\begin{array}{l}0.88 \log \text { in APC, } 1.2 \log \text { in } \\
\text { Enterobacteriaceae, } 1.51 \log \text { in } \\
\text { enterococci count }\end{array}$ & $\begin{array}{l}\text { Sallam et al., } \\
2020\end{array}$ \\
\hline & $\begin{array}{l}\mathrm{TSP}(10 \%) \text { on rainbow } \\
\text { trout }\end{array}$ & $\begin{array}{l}0.8 \text { and } 0.9 \log \mathrm{CFU} / \mathrm{g} \text { in } \mathrm{APC} \text { and } \\
\text { Lactic acid bacteria respectively }\end{array}$ & $\begin{array}{l}\text { Dikici et al., } \\
2021\end{array}$ \\
\hline
\end{tabular}

the effect of various organic acids like lactic, acetic, citric, propionic, ascorbic, formic, and peracetic acid etc. as meat/fish surface decontaminants. Acetic acid, citric acid and lactic acid are generally recognized as safe (GRAS as per Codes of Federal Regulation,
USFDA) and their solutions at $1.5-2.5 \%$ are approved by USDA-FSIS as carcass decontaminants. The application of lactic acid and acetic acid spray significantly reduce microbial population on beef surfaces and trout fish (Carranza et al., 2013; Sallam et al., 2020; 
Dikici et al., 2021). The application of peracetic acid (PAA) is more effective than chlorine water in reducing the E.coli in fish as the PAA does not get affected by organic matter rapidly (Thi et al., 2015). These are inexpensive, easy to apply and generally do not affect the sensory qualities of meat/fish, if applied at low concentration.

Chlorine based products: Chlorine is widely used as antimicrobial agent. When chlorine is added to water, it forms hydrochloric acid, hypochlorous acid and hypochlorite ions which disrupt the bacterial cell wall, damage the bacterial enzymes and DNA. Chlorine dioxide is less toxic and more stable than chlorinated water, so it can replace chlorinated water for chicken processing (Sefna et al., 2019). Though chlorine is effective, inexpensive and easy to apply, but it gets inactivated rapidly when comes in contact with meat. It may also produce harmful chemical residues and by-products, affects sensory qualities, and promote chlorine-resistant strains of Salmonella, if used at high concentration.

Acidified sodium chlorite (ASC) can be used as an efficient alternative to chlorine. The use of ASC at $<1200 \mathrm{ppm}$ has been approved for decontamination of meat and in countries, like Canada, European Union and New Zealand, ASC at a level of $1200 \mathrm{ppm}$ is also reported to be effective in surface decontamination of trout fish (Dikici et al., 2021). ASC generates chlorous acid which penetrates the bacterial cell wall and disrupts protein synthesis. It is effective in reducing S. typhimurium on meat surface (Ilhak et al., 2018). Its bactericidal effect depends on preparation procedure and initial reactants concentrations. ASC prepared by DAR method i.e. premixing of sodium chlorite and acid, followed by dilution after reaction (DAR), is more effective than the conventional ASC preparation (mixing equal volume of $\mathrm{SC}$ and acid). The ASC-DAR (10 ppm, $5 \mathrm{~min})$ completely inactivated all the test pathogens (Kim et al., 2014). Therefore, this can be used to maximize the bactericidal action of ASC.
Another chlorine-based compound, Cetylpyridinium chloride (CPC) is also effective in reducing L.monocytogenes, Campylobacter Spp. and S. Typhimurium on meat surface without affecting the quality (Zhang et al., 2018). CPC (0.5\%) is more effective than 1200 ppm ASC in reducing Listeria. (Ilhak et al., 2018). CPC reduces microbial load of rainbow trout without affecting its texture adversely (Dikici et al., 2021).

Tri sodium phosphate: Tri sodium phosphate (TSP) is as an antimicrobial treatment approved by USDA-FSIS for beef and poultry carcass. It is able to inactivate enterococci, enterobacteriaceae, coliforms and Staph. Aureus and also minimizes adherence of microorganisms to carcass. $12 \%$ TSP is less effective than $2 \%$ lactic acid or acetic acid treatment (Sallam et al., 2020). 10\% TSP is effective as surface decontaminant but, it causes whitening in trout fish (Dikici et al., 2021). So, it is inexpensive and easy to apply, but it can affect colour and flavour of the muscle food when used at higher concentration.

Ozone: Ozone is produced by passing the electric charges or ionizing radiation through air or oxygen. It is a powerful oxidizing agent used to inactivate bacteria like E. coli $0157: \mathrm{H} 7$, S. typhimurium, Pseudomonas fluorescens on several muscle foods. Ozone treated chilled poultry showed better control of aerobic bacteria and Enterobacteriaceae during storage (Cortesi et al., 2011).

\section{Biological treatment for surface decontamination of muscle foods}

Not many researches have been done to explore the efficacy of the biological treatments for surface decontamination of muscle food. Bacteriophages and bacteriocins have the potential for use as surface decontaminants, but it is important to establish their sufficient antimicrobial activity under industrial conditions and eliminate the challenge of potential resistance development. Bacteriophage reduces Salmonella and 
Campylobacter count on chicken surface, but there is a need for more studies at commercial level (Zweifel and Stephan, 2012). The $V$. parahaemolyticus - specific phage OMN (vB_VpaS_OMN) can inactivate $90-99 \%$ of $V$. parahaemolyticus on oyster surface when applied for 48-72 hrs (Zhang et al., 2018).

The EFSA evaluated the safety and efficacy of ListexTM P100 as spray or dip to reduce L. monocytogenes contamination on raw fish surface. ListexTM P100 contains bacteriophage (P100) which kills only Listeria. Also, it is not considered as harmful to the consumers. The EFSA considered two studies conducted under laboratory condition on artificially contaminated raw fish and ListexTM P100 was effective against $L$. monocytogenes. But the future study has to be conducted to establish the listericidal effect of bacteriophage in naturally contaminated fish, at industrial level and also to prove the reduction of potential human listeriosis risk by this bacteriophage treatment of raw fish (EFSA, 2012).

\section{Novel technologies for surface decontamination of muscle foods}

To avoid the adverse effects of thermal physical decontamination methods and the chemical decontaminants, the researchers have been exploring the efficacies of various non thermal physical methods. Some of these novel technologies for meat/fish carcass decontamination are reviewed here (Table 2).

Ultrasound: It is a form of energy generated by a sound wave with a frequency $(20 \mathrm{kHz}$ or more) greater than the upper limit of the human hearing range. The high power ultrasound inactivates microorganisms by generating intracellular cavitation which ultimately results in thinning of cell membranes, heating and production of free radicals. As ultrasonic waves are safe and non-toxic, ultrasound can be used as a "green technology" to improve the muscle food quality and safety (Turantas et al., 2015). But the ultrasound cannot always give the desired results when applied alone. The combination of ultrasound with other methods (steam, chlorine, ethanol, lactic acid, plasma) contributes to the enhancement of microbial inactivation (Morild et al., 2011; Lee et al., 2014; Musavian et al., 2014; Seo et al., 2019). The ultrasound treatment on fish (salmon, mackerel, cod, hake) can reduce the mesophilic and Psychrophilic bacteria, Enterobacteriaceae and pseudomonas spp. significantly without much affecting the colour of fish; it is faster and more cost effective than conventional decontamination methods (PedrosGarrido et al., 2017).

Irradiation: It is suitable for the decontamination of fresh meat/fish as it can be used as bactericidal and it does not substantially increase the product temperature or affect the sensory quality. The Joint Expert Committee of FAO, WHO and IAEA (International Atomic Energy Agency) has established that there is no threat of toxicological, microbiological or nutritional hazard if irradiation up to $10 \mathrm{k}$ Gy dose is applied in food. The USFDA approved a maximum dose of $4.5 \mathrm{k}$ Gy irradiation to treat unrefrigerated uncooked meat and certain meat products for reducing the foodborne pathogens (USFDA, 2020). Ionizing radiation may be either in the form of gamma and X-rays or electron beam (E-beam). It damages or kills bacteria by destroying DNA, RNA and protein. Irradiation of meat with high doses may lead to off-odours in meat, primarily due to lipid oxidation. But, low-dose, low-penetration Ebeam irradiation can be used as an antimicrobial on beef carcass without affecting much its sensory qualities (Arthur et al., 2005). E-beam irradiation at $1 \mathrm{k}$ Gy reduces E. coli $\mathrm{O} 157: \mathrm{H} 7$ and Salmonella on beef surface (Kundu et al., 2014). Low penetration E-beam with uniform dose distribution on rabbit carcass surface significantly reduced E. coli O157:H7 (Maxim et al., 2014). The gamma radiation (1 to $3 \mathrm{k}$ Gy) inactivates psychrophiles and Enterococcus bacteria on turkey breast samples (Henry et al., 2010).

Ultraviolet (UV-C): Light UV-C (200-280 nm wave length) inactivates the bacteria, viruses, and other pathogens by disrupting their DNA 
Table 2. Overview of novel surface decontamination technologies

\begin{tabular}{|c|c|c|c|}
\hline $\begin{array}{l}\text { Decontamination } \\
\text { treatment }\end{array}$ & Application & Microbial reduction & Reference \\
\hline \multirow{3}{*}{ Irradiation } & $\begin{array}{l}\text { E-beam irradiation ( } 1 \mathrm{k} \\
\text { Gray) on beef surface }\end{array}$ & $\begin{array}{l}\leq 4.5 \mathrm{log} \text { CFU/g in VTEC, } \leq 4.0 \log \\
\mathrm{CFU} / \mathrm{g} \text { in E. coli } \mathrm{O} 157: \mathrm{H} 7 \text { and } \\
\leq 1.9 \mathrm{log} \text { CFU/g in Salmonella }\end{array}$ & $\begin{array}{l}\text { Kundu et al., } \\
2014\end{array}$ \\
\hline & $\begin{array}{l}\text { E-beam irradiation }(10 \mathrm{Me} \\
\mathrm{V}) \text { on inoculated rabbit } \\
\text { carcass }\end{array}$ & $5 \log$ in E. coli $\mathrm{O} 157: \mathrm{H} 7$ & $\begin{array}{l}\text { Maxim et al., } \\
2014\end{array}$ \\
\hline & $\begin{array}{l}\text { Gamma radiation ( } 1 \text { to } 3 \mathrm{k} \\
\text { Gy) on turkey breast }\end{array}$ & $\begin{array}{l}\text { Significant reduction in } \\
\text { psychrophiles and Enterococcus } \\
\text { bacteria }\end{array}$ & $\begin{array}{l}\text { Henry et al., } \\
2010\end{array}$ \\
\hline \multirow{3}{*}{ Ultrasound } & $\begin{array}{l}\text { Ultrasound + steam }(30-40 \\
\mathrm{kHz}, 2 \text { sec. }+130^{\circ} \mathrm{C}, 3.5- \\
5 \mathrm{~atm}) \text { on pork }\end{array}$ & $\begin{array}{l}2.5 \log \mathrm{CFU} / \mathrm{cm}^{2}, 2 \log \mathrm{CFU} / \mathrm{cm}^{2} \\
\text { and } 2.1 \log \mathrm{CFU} / \mathrm{cm}^{2} \text { in } E \text {. coli, } \\
\text { S. typhimurium, Y. enterocolitica } \\
\text { respectively }\end{array}$ & $\begin{array}{l}\text { Morild et al., } \\
2011\end{array}$ \\
\hline & $\begin{array}{l}\text { Ultrasound + Lactic acid } \\
(40 \mathrm{kHz}, 1 \% \mathrm{LA}) \text { on } \\
\text { Chicken wing skin }\end{array}$ & $\begin{array}{l}\leq 4.0 / \mathrm{cm} 2 \text { in Gram-negative } \\
\text { bacteria }\end{array}$ & $\begin{array}{l}\text { Kordowska- } \\
\text { Wiater and } \\
\text { Stasiak (2011) }\end{array}$ \\
\hline & $\begin{array}{l}\text { Ultrasound (5-45 minutes) } \\
\text { on salmon, mackerel, cod } \\
\text { and hake fish }\end{array}$ & $\begin{array}{l}0.5-1.1 \log \mathrm{CFU} / \mathrm{g} \text { in mesophilic } \\
\text { count, } 0.6-1.5 \mathrm{log} \mathrm{CFU} / \mathrm{g} \text { in } \\
\text { psychrophilic count, } 0.7-0.8 \mathrm{log} \\
\mathrm{CFU} / \mathrm{g} \text { in Enterobacteriaceae, } 0.6- \\
1.3 \text { in Pseudomonas spp. }\end{array}$ & $\begin{array}{l}\text { Pedros- } \\
\text { Garrido et al., } \\
2017\end{array}$ \\
\hline \multirow{2}{*}{ UV light } & $\begin{array}{l}\text { UV-C light }\left(590 \mathrm{~mJ} / \mathrm{cm}^{2}\right) \\
\text { on beef }\end{array}$ & $\begin{array}{l}1.19 \log \mathrm{CFU} / \mathrm{cm}^{2} \text { in } \text { E. coli, } 1.08 \\
\log \mathrm{CFU} / \mathrm{cm} 2 \text { in Salmonella } \text { strains } \\
\text { and } 0.89 \log \mathrm{CFU} / \mathrm{cm} 2 \text { in Listeria } \\
\text { monocytogenes }\end{array}$ & $\begin{array}{l}\text { Kalchayanand } \\
\text { et al., } 2020\end{array}$ \\
\hline & $\begin{array}{l}\text { UV -C light }\left(2040 \mathrm{~mJ} / \mathrm{cm}^{2}\right) \\
\text { on pork }\end{array}$ & $\begin{array}{l}0.56 \log \mathrm{CFU} / \mathrm{g} \text { in Yersinia } \\
\text { enterocolitica }\end{array}$ & $\begin{array}{l}\text { Reichel et al., } \\
2019\end{array}$ \\
\hline \multirow[t]{3}{*}{ Pulsed UV light } & $\begin{array}{l}\text { Pulsed UV light ( } 3 \text { pulses/ } \\
\text { second, pulse duration of } \\
360 \mu \text { s, for } 30 \mathrm{~s} \text { to } 180 \mathrm{~s} \text { ) } \\
\text { on whole chicken carcass }\end{array}$ & $\begin{array}{l}0.87 \text { to } 1.43 \log \mathrm{CFU} / \mathrm{ml} \text { in } E \text {. coli } \\
\mathrm{K} 12 \text { after } 30-\mathrm{s} 180 \mathrm{~s} \text { treatments }\end{array}$ & $\begin{array}{l}\text { Keklik et al., } \\
2011\end{array}$ \\
\hline & $\begin{array}{l}\text { Pulsed UV light }(0.52- \\
\left.19.11 \mathrm{~J} / \mathrm{cm}^{2}\right) \text { on Pork skin }\end{array}$ & $\begin{array}{l}3.16 \log \mathrm{CFU} / \mathrm{cm} 2 \text { in Salmonella } \\
\text { typhimurium and } 4.37 \log \mathrm{CFU} / \\
\mathrm{cm} 2 \text { in Yersinia enterocolitica }\end{array}$ & $\begin{array}{l}\text { Koch et al., } \\
2018\end{array}$ \\
\hline & $\begin{array}{l}\text { Pulsed UV light ( } 5 \text { to } 30 \mathrm{~J} / \\
\mathrm{cm}^{2} \text { ) on chicken thigh and } \\
\text { breast }\end{array}$ & $\begin{array}{l}0.29 \text { and } 1.04 \text { in E. coli on breast, } \\
0.34 \text { and } 0.94 \text { on thigh }\end{array}$ & $\begin{array}{l}\text { Cassar et al., } \\
2021\end{array}$ \\
\hline
\end{tabular}


Cont. Table 2.

\begin{tabular}{|c|c|c|c|}
\hline $\begin{array}{l}\text { Decontamination } \\
\text { treatment }\end{array}$ & Application & Microbial reduction & Reference \\
\hline \multirow{4}{*}{ Cold plasma } & $\begin{array}{l}\text { i. Dielectric barrier } \\
\text { discharge (DBD) plasma } \\
\left(\mathrm{N}_{2} \text { and } \mathrm{O}_{2}, 2 \mathrm{~W}, 15 \mathrm{kHz},\right. \\
\text { for } 10 \mathrm{~min}) \text { on Beef }\end{array}$ & $\begin{array}{l}1.90 \log \mathrm{CFU} / \mathrm{g} \text { in Listeria } \\
\text { monocytogenes, } 2.57 \log \mathrm{CFU} / \mathrm{g} \text { in } \\
\text { E.coli O157:H7 } 2.58 \mathrm{log} \mathrm{CFU} / \mathrm{g} \text { in } \\
\text { Salmonella typhimurium }\end{array}$ & $\begin{array}{l}\text { Jayasena et al., } \\
2015\end{array}$ \\
\hline & $\begin{array}{l}\text { ii. DBD plasma }(2-100 \mathrm{~W} \text {, } \\
15 \mathrm{kHz}, 10 \mathrm{~min}) \text { on chicken } \\
\text { breast }\end{array}$ & $\begin{array}{l}2.14 \log \mathrm{CFU} / \mathrm{g} \text { in Listeria } \\
\text { monocytogenes, } 2.73 \mathrm{log} \mathrm{CFU} / \mathrm{g} \text { in } \\
\text { E. coli, and } 2.71 \mathrm{log} \mathrm{CFU} / \mathrm{g} \text { in } \\
\text { Salmonella typhimurium }\end{array}$ & $\begin{array}{l}\text { Lee } e t \text { al., } \\
2016\end{array}$ \\
\hline & $\begin{array}{l}\text { iii. Atmospheric pressure } \\
\text { plasma jet }(1 \mathrm{MHz}, 2-3 \\
\mathrm{kV} .180 \mathrm{~s}) \text { on chicken skin } \\
\text { and breast. }\end{array}$ & $\begin{array}{l}2.5 \log \mathrm{CFU} / \mathrm{cm}^{2} \text { in } \\
\text { Campylobacter jejuni }\end{array}$ & $\begin{array}{l}\text { Rossow et al., } \\
2018\end{array}$ \\
\hline & $\begin{array}{l}\text { iv. Plasma-activated water } \\
\text { and ultrasound }(1.5 \mathrm{MHz} \text {, } \\
6.8 \mathrm{kV}, 40 \mathrm{~Hz} .60 \mathrm{~min} \text {, } \\
\left.40^{\circ} \mathrm{C}\right) \text { on chicken skin }\end{array}$ & $\begin{array}{l}1.12 \log \mathrm{CFU} / \mathrm{mL} \text { in E. coli } \mathrm{K} 12 \\
\text { and } 0.86 \log \mathrm{CFU} / \mathrm{mL} \text { in } \\
\text { Staphylococcus aureus }\end{array}$ & $\begin{array}{l}\text { Royintarat } \\
\text { et al., } 2020\end{array}$ \\
\hline
\end{tabular}

and multiplication. Several researchers observed significant microbial reduction on the meat surface (chicken, beef, pork) and reported that there was minimal to zero adverse effect on colour or texture (Oh et al., 2014; Reichel et al., 2019; Kalchayanand et al., 2020). Though UV-C alone can reduce microbe numbers, but cannot eliminate them completely. It improves the microbial safety of food in a better way when used in combination with other decontamination treatments.

Pulsed UV light: It can be used to inactivate microorganisms on surfaces in very short time. The decontamination efficiency of pulses of light is higher than the continuous application of UV-light. It inactivates the microbes by damaging DNA, thermal stress, and pulse disturbance effects (Krishnamurthy et al., $2010)$. Generally, very short ( $\mu$ s) high power pulses of UV light are generated by using inert gas flash lamps. The treatment of chicken carcass and pork skin with pulsed UV light resulted in the significant microbial reductions (Keklik et al., 2011; Koch et al., 2018; Cassar et al., 2021). Chicken meat temperatures increased with longer treatment times. The optimum treatment time was $45 \mathrm{~s}$ and it caused $1 \log$ microbial reduction without affecting meat colour or increasing the temperature too high. The effectiveness of the pulsed UV light treatment may be increased by optimizing the system design and/or combining it with other antimicrobial treatment (Keklik et al., 2011).

Cold atmospheric plasma: This non-thermal emerging technology is being used for food safety in recent years. This can reduce foodborne pathogens effectively without affecting much the product quality (Lee et al., 2016). The cold plasma can kill microbes because it consists of excited atoms and molecules, UV photons, electrons, ions, free radicals and reactive species (Baek et al., 2020). These kill microbes by damaging cell membrane, cell wall, RNA, DNA and denaturing proteins (Misra and Jo, 2017; Baek et al., 2020). The researchers have used various forms of cold plasma, like dielectricbarrier discharge (DBD) cold plasma, direct treatment with plasma jet, plasma-activated water, combining atmospheric cold plasma treatment with peracetic acid application, combining plasma-activated water with ultrasound etc. (Royintarat et al., 2020). All the 
studies reported successful minimization in microbial load and combination treatments improved the antibacterial effects. The plasma treatment causes no changes or very little changes in meat quality (Jayasena et al., 2015) and leaves no harmful residue in meat. Therefore, this environment friendly treatment has great potential to decontaminate muscle food.

\section{Hurdle technology for surface decontamination of muscle foods}

Majority of the decontamination treatments cannot give desired results when applied alone, but when they combine with other treatments, they are very effective in microbial inactivation. As steam/hot water decontamination treatment of broiler carcasses is hindered due to adverse effects on broiler skin, a combination of steam with ultrasound treatment can significantly reduce numbers of Campylobacter without affecting the sensory quality (Musavian et al., 2014). The steam-ultrasound treatment $\left(130{ }^{\circ} \mathrm{C} / 3.5-5\right.$ atm. steam and $30-40 \mathrm{kHz}$ ultrasound) on meat surfaces significantly reduces Salmonella typhimurium, $Y$. enterocolitica and E. coli (Morild et al., 2011). For microbial inactivation on chicken skin, ultrasound treatment in lactic acid solution is more effective than ultrasound in water; and the effectiveness increases with increase in sonication time (Kordowska-Wiater and Stasiak, 2011). The cold plasma treatment combined with peracetic acid, plasma-activated water treatment with ultrasound (Royintarat et al., 2020) also give better antimicrobial results in comparison to the application of cold plasma alone.

\section{Conclusion}

The antimicrobial effect of the surface decontaminants on muscle food depends on variety of conditions, like contamination levels, physical/chemical nature of decontaminants, concentration/dose, application modes, temperatures, pressures, exposure times etc. All the thermal physical methods are safer as they don't leave harmful chemical residues and they are environment-friendly, but may have adverse effect on the food quality if the temperature is too high or exposure time is more. The chemical decontaminants are effective antimicrobial, low cost and easy to apply, but they may leave harmful residues, affect sensory qualities adversely and may also result in resistant microbial strains, if used in high concentrations. Biological treatments showed effective surface decontamination effect, but their applicability in commercial level is not well established. All the non-thermal novel technologies are environment-friendly, do not leave harmful residue, and usually sufficient alone to significantly reduce the pathogenic load on carcass surface. Though these are mostly being used in the laboratory conditions, further researches may be conducted to optimize individual treatment and also explore the synergistic effect of combination of treatments for providing best surface decontaminants while maintaining the food quality. Combination of decontamination treatments (hurdle technology) may be a unique approach to achieve the reduced microbial risk by balancing the adverse effects of one treatment and taking the advantages of additive effects of multiple treatments. Therefore, meat/fish industries can apply the above mentioned decontamination methods as per their choice/suitability, provided the method is approved by the regulatory authority of that country and also the importing countries. It can be concluded that the surface decontamination of muscle foods is an important control measure in the meat/fish processing for ensuring the safety, but it should always be accompanied with other good food manufacturing, hygienic and sanitary practices.

Conflict of interest: Authors have no conflict of interest in this study.

Author's contribution: The authors have conceptualized the article, collected, analysed and interpreted the secondary data.

\section{ACKNOWLEDGMENTS}

The authors are grateful to the Editorial Board of IJAH for suggesting the tentative topic of the review article. 


\section{REFERENCES}

Arthur TM, Wheeler TL, Shackelford SD, Bosilevac JM, Nou X et al., 2005. Effects of low-dose, lowpenetration electron beam irradiation of chilled beef carcass surface cuts on Escherichia coli $\mathrm{O} 157: \mathrm{H} 7$ and meat quality. J Food Prot, 68(4): 666-672, doi:10.4315/0362-028X68.4.666

Baek KH, Yong HI, Yoo JH, Kim JW, Byeon YS et al., 2020. Antimicrobial effects and mechanism of plasma activated fine droplets produced from arc discharge plasma on planktonic Listeria monocytogenes and Escherichia coli O157:H7. J Phys D Appl Phys, 53(12): e 124002

Barco L, Belluco S, Roccato A and Ricci A, 2015. A systematic review of studies on Escherichia coli and Enterobacteriaceae on beef carcasses at the slaughterhouse, Int J Food Microbiol, 207: 3039, doi: 10.1016/j.ijfoodmicro.2015.04.027

Belluco S, Barco L, Roccato A and Ricci A, 2016. Escherichia coli and Enterobacteriaceae counts on poultry carcasses along the slaughterline: A systematic review and meta-analysis. Food Control, 60: 269-280, doi: 10.1016/ j.foodcont.2015.07.033

Carranza LR, Lozano MSR, Medina RDM, Rodarte MCW, Espinosa JFN et al., 2013. Acetic acid as an intervention strategy to decontaminate beef carcasses in Mexican commercial slaughterhouse. Food Sci Technol, 33(3): 446-450, doi: 10.1590/S0101-20612013005000065

Cassar JR, Mills EW, Campbell JA and Demicri A, 2021. Pulsed ultraviolet light treatment of chicken parts. Meat Muscle Biol, 5(1): 28, doi: 10.22175/mmb. 12256

CDC, Centre for Disease Control and Prevention, 2017. Surveillance for Foodborne Disease Outbreaks United States, 2017: Annual Report. Available i n w w w . c d c.g o v / f d o s s / p d f / 2017_FoodBorneOutbreaks_508.pdf [25.09.2021]

Chen JH, Ren Y, Seow J, Liu T, Bang WS et al., 2012. Intervention technologies for ensuring microbiological safety of meat: current and future trends. Compr Rev Food Sci Food Saf, 11(2): 119132, doi: 10.1111/j.1541-4337.2011.00177.x

Cortesi ML, Sarno E and Costanzo N, 2011. Ozone decontamination of chilled poultry carcasses. Italian J Food Safety, 1(1): 51, doi: 10.4081/ ijfs.2011.1.51

Das AK, Nanda PK, Das A and Biswas S, 2019. Hazards and Safety Issues of Meat and Meat Products.
In:Food Safety and Human Health, pp 145-168, doi:10.1016/B978-0-12-816333-7.00006-0

Dikici A, Özpolat E, Bozatli SB, Koluman A, Patir B et al., 2021. Investigating the effect of decontaminants on microbiological and chemical properties of rainbow trouts. Turkish J Vet Anim Sci, 45: 691-699, doi: 10.3906/vet-2011-39

EFSA (European Food Safety Authority), 2012. EFSA Panel on Biological Hazards (BIOHAZ); Scientific opinion on the evaluation of the safety and efficacy of ListexTM P100 for the removal of Listeria monocytogenes surface contamination of raw fish. EFSA J, 10(3): 2615, doi: 10.2903/j.efsa.2012.2615

FSSR, Food Safety and Standards (Food products standards and food additives) Regulation, 2011. Available in https://fssai.gov.in/upload/ uploadfiles/files/Compendium_Food_ Additives_ Regulations_08_09_2020compressed.pdf. (25 Sep, 2021)

Hauge SJ, Wahlgren M, Ole-Johan Røtterud and Nesbakken T, 2011. Hot water surface pasteurisation of lamb carcasses: microbial effects and cost-benefit considerations. Int $\mathrm{J}$ Food Microbiol, 146(1): 69-75, doi: 10.1016/ j.ijfoodmicro.2011.02.003

Henry FC, Silva TJP, Franco RM, Freitas MQ and De Jesus EFO, 2010. Effect of gamma radiation on frozen turkey breast meat quality. J Food Safety, 30(3): 615-634, doi: $10.1111 / \mathrm{j} .1745-$ 4565.2010.00229.x

Hochreutener M, Zweifel C, Corti S and Stephan R, 2017. Effect of a commercial steam-vacuuming treatment implemented after slaughtering for the decontamination of cattle carcasses. Italian J Food Safety, 6(3): 6864, doi: 10.4081/ijfs.2017.6864

Ilhak OI, Incili GK and Durmupoðlu H, 2018. Effect of some chemical decontaminants on the survival of Listeria monocytogenes and Salmonella typhimurium with different attachment times on chicken drumstick and breast meat. J Food Sci Technol, 55(8): 3093-3097, doi: 10.1007/ s13197-018-3234-7

Jayasena DD, Kim HJ, Yong HI, Park S, Kim Ket al., 2015. Flexible thin-layer dielectric barrier discharge plasma treatment of pork butt and beef loin: effects on pathogen inactivation and meatquality attributes. Food Microbiol, 46: 5157, doi: 10.1016/j.fm.2014.07.009

Kalchayanand N, Bosilevac JM, King DA and Wheeler TL, 2020. Evaluation of UVC radiation and a UVC-ozone combination as fresh beef 
interventions against Shiga toxin-producing Escherichia coli, Salmonella, and Listeria monocytogenes and their effects on beef quality. J Food Prot, 83(9): 1520-1529, doi: 10.4315/JFP19-473

Keklik NM, Demirci A and Bock RG, 2011. Surface decontamination of whole chicken carcasses using a pilot-scale pulsed uv light system.Trans ASABE, 54(3): 993-1000, doi: 10.13031/ 2013.37083)@2011

Kim NH, Park TH and Rhee MS, 2014. Enhanced bactericidal action of acidified sodium chlorite caused by the saturation of reactants.J Appl Microbiol, 116(6): 1447-1457, doi:10.1111/ jam. 12484

Koch F, Wiacek C and Braun PG, 2018. Pulsed light treatment for the reduction of Salmonella Typhimurium and Yersinia enterocolitica on pork skin and pork loin. Int J Food Microbiol, 292: 64-71, doi:10.1016/j.ijfoodmicro.2018.11.014.

Kordowska-Wiater M and Stasiak DM, 2011. Effect of ultrasound on survival of gramnegative bacteria on chicken skin surface. Bull Vet Inst Pulawy, 55: $207-210$

Krishnamurthy K, Tewari JC, Irudayaraj J and Demirci A, 2010. Microscopic and spectroscopic evaluation of inactivation of Staphylococcus aureus by pulsed UV light and infrared heating. Food Bioproc Tech, 3(1): 93-104, doi: 10.1007/s11947008-0084-8

Kundu D, Gill A, Lui C, Goswami N and Holley R, 2014. Use of low dose e-beam irradiation to reduce $E$. coli O157:H7, non-O157 (VTEC) E. coli and Salmonella viability on meat surfaces. Meat Sci, 96(1): 413418, doi: 10.1016/j.meatsci. 2013.07.034

Lee H, Yong HI, Kim HJ, Choe W, Yoo SJ et al., 2016. Evaluation of the microbiological safety, quality changes, and genotoxicity of chicken breast treated with flexible thin-layer dielectric barrier discharge plasma. Food Sci Biotechnol, 25(4): 1189-1195, doi: 10.1007/s10068-016-0189-1

Lee NY, Park SY, Kang IS and Ha SD, 2014. The evaluation of combined chemical and physical treatments on the reduction of resident microorganisms and Salmonella typhimurium attached to chicken skin. Poult Sci, 93(1): 208215, doi: 10.3382/ps.2013-03536

Maxim JE, Neal JA and Castillo A, 2014. Development of a novel device for applying uniform doses of electron beam irradiation on carcasses. Meat Sci, 96: 373-378, doi:10.1016/j.meatsci.2013.07.030

Misra NN and Jo C, 2017. Applications of cold plasma technology for microbiological safety in meat industry. Trend Food Sci Technol, 64: 74-86, doi: 10.1016/j.tifs.2017.04.005

Morild RK, Christiansen P, Sorensen AH, Nonboe U and Aabo S, 2011. Inactivation of pathogens on pork by steam-ultrasound treatment. J Food Prot, 74(5): 769-775, doi: 10.4315/0362-028X.JFP-10338

Musavian HS, Krebs NH, Nonboe U, Corry JE and Purnell G, 2014. Combined steam and ultrasound treatment of broilers at slaughter: A promising intervention to significantly reduce numbers of naturally occurring campylobacters on carcasses. Int J Food Microbiol, 176: 23-28, doi: 10.1016/ j.ijfoodmicro.2014.02.001

Novoslavskij A, Terentjeva M, Eizenberga I, Olga V, Bartkevics V et al., 2016. Major foodborne pathogens in fish and fish products: A review. Ann Microbiol, 66: 1-15, doi: 10.1007/s13213-0151102-5

Oh SR, Kang I, Oh MH and Ha SD, 2014. Inhibitory effect of chlorine and ultraviolet radiation on growth of Listeria monocytogenes in chicken breast and development of predictive growth models. Poult Sci, 93(1): 200-207, doi: 10.3382/ ps.2013-03394

Pedros-Garrido S, Condón-Abanto S, Beltrán JA, Lyng JG, Brunton NP et al., 2017. Assessment of high intensity ultrasound for surface decontamination of salmon (S. salar), mackerel (S. scombrus), cod (G. morhua) and hake (M. merluccius) fillets, and its impact on fish quality. Innov Food Sci Emerg Technol, 41: 64-70, doi: 10.1016/ j.ifset.2017.02.006

Reichel J, Kehrenberg C and Krischek C, 2019. Inactivation of Yersinia enterocolitica and Brochothrix thermosphacta on pork by UV-C irradiation. Meat Sci, 158: 1-8, doi: 10.1016/ j.meatsci.2019.107909

Rossow M, Ludewig M and Braun PG, 2018. Effect of cold atmospheric pressure plasma treatment on inactivation of Campylobacter jejuni on chicken skin and breast fillet. LWT-Food Sci Technol, 91: 265-270, doi: 10.1016/j.lwt.2018.01.052

Royintarat T, Choi EH, Boonyawan D, Seesuriyachan P and Wattanutchariya W, 2020. Chemical-free and synergistic interaction of ultrasound combined with plasma-activated water (PAW) to enhance microbial inactivation in chicken meat and skin. Sci Rep, 10(1): e1559, doi: 10.1038/s41598-02058199-w

SallamKI, Abd-Elghany SM, Hussein MA, Imre K, 
Morar A et al., 2020. Microbial decontamination of beef carcass surfaces by lactic acid, acetic acid, and trisodium phosphate sprays. BioMed Res Int, doi: $10.1155 / 2020 / 2324358$

Sandra da Silva and Farag K, 2020. The impact of lamb cleanliness and line speed on the effectiveness of steam vacuum and carcass wash as decontamination methods after slaughter. Meat Sci, 171: 108276, doi: 10.1016/j.meatsci. 2020.108276

Sefna V, Irshad A, Arun Sankar KJ, Lakshmi AT and Vasudevan VN, 2019. The use of chlorine dioxide solution as an effective decontaminant for broiler chicken carcass. Int J Livest Res, 9(8): 268-279, doi: $10.5455 /$ ijlr.20190604090949

Seo MK, Jeong HL, Han SH, Kang I and Ha SD, 2019. Impact of ethanol and ultrasound treatment on mesophilic aerobic bacteria, coliforms, and Salmonella typhimurium on chicken skin. Poult Sci, 98(12): 6954-6963, doi: 10.3382/ps/pez486

Thi ANT, Sampers I, Haute SV, Samapundo S, Nguyen BL et al., 2015. Decontamination of Pangasius fish (Pangasius hypophthalmus) with chlorine or peracetic acid in the laboratory and in a Vietnamese processing company. Int J Food Microbiol, 208: 93-101, doi: 10.1016/ j.ijfoodmicro.2015.05.017

Turantas F, Kýlýç GB and Kılıç B, 2015. Ultrasound in the meat industry: general applications and decontamination efficiency. Int J Food Microbiol, 198: 59-69, doi: 10.1016/j.ijfoodmicro. 2014.12.026

USFDA, United States Food and Drug Administration, 2020. Ionizing radiation for the treatment of food. 21 CFR 179.26. http://www.accessdata. fda.gov/ scripts/cdrh/cfdocs/cfcfr/cfrsearch.cfm?fr=179.26 (25 Sep, 2021)

WHO, World Health Organization, 2020. Food safety key facts, available in: https://www.who.int/newsroom/fact-sheets/detail/food-safety (25 Sep, 2021)

Zhang H, Yang Z, Zhou Y, Bao H, Wang R et al., 2018. Application of a phage in decontaminating Vibrio parahaemolyticus in oysters. Int J Food Microbiol, 275: 24-31, doi: 10.1016/j.ijfoodmicro. 2018.03.027

Zhang L, Garner LJ, McKEE SR and Bilgili SF, 2018. Effectiveness of several antimicrobials used in a postchill decontamination tank against Salmonella and Campylobacter on broiler carcass parts. J Food Prot, 81(7): 1134-1141, doi: 10.4315/ 0362-028X.JFP-17-507

Zweifel C and Stephan R, 2012. Microbial decontamination of poultry carcasses. Woodhead Publishing Series in Food Science, Technology and Nutrition, pp 60-95, doi: 10.1533/ 9780857095756.1 .60 